\title{
The common G-866A polymorphism of the UCP2 gene and survival in diabetic patients following myocardial infarction
} Barry R Palmer*1, Courtney L Devereaux ${ }^{1,4}$, Sukhbir S Dhamrait ${ }^{2}$, Tessa J Mocatta ${ }^{3}$, Anna P Pilbrow ${ }^{1}$, Chris M Frampton ${ }^{1}$, Lorraine Skelton ${ }^{1}$, Tim G Yandle ${ }^{1}$, Christine C Winterbourn ${ }^{3}$, A Mark Richards ${ }^{1}$, Hugh E Montgomery ${ }^{2}$ and Vicky A Cameron ${ }^{1}$

Address: ${ }^{1}$ Christchurch Cardioendocrine Research Group, Department of Medicine, University of Otago, Christchurch, PO Box 4345 , Christchurch, New Zealand, ${ }^{2}$ Centre for Cardiovascular Genetics, British Heart Foundation Laboratories, Royal Free and University College London Medical School, London WC1E 6JF, UK, ${ }^{3}$ Free Radical Research Group, Department of Pathology, University of Otago, Christchurch, PO Box 4345, Christchurch, New Zealand and ${ }^{4}$ Current address : University of Denver, 2199 S. University Blvd., Denver, Colorado 80208, USA

Email: Barry R Palmer* - barry.palmer@otago.ac.nz; Courtney L Devereaux - courtney.devereaux@du.edu; Sukhbir S Dhamrait - sukhbirdhamrait@hotmail.com; Tessa J Mocatta - tessa.mocatta@otago.ac.nz; Anna P Pilbrow - anna.pilbrow@otago.ac.nz; Chris M Frampton - statistecol@xtra.co.nz; Lorraine Skelton - lorraine.skelton@cdhb.govt.nz; Tim G Yandle - tim.yandle@cdhb.govt.nz; Christine C Winterbourn - christine.winterbourn@otago.ac.nz; A Mark Richards - mark.richards@cdhb.govt.nz; Hugh E Montgomery - rmhahum@ucl.ac.uk; Vicky A Cameron - vicky.cameron@otago.ac.nz * Corresponding author

Published: 15 June 2009

Cardiovascular Diabetology 2009, 8:31 doi:10.1 I86/|475-2840-8-31
Received: 3 April 2009

Accepted: 15 June 2009

This article is available from: http://www.cardiab.com/content/8/I/3 I

(C) 2009 Palmer et al; licensee BioMed Central Ltd.

This is an Open Access article distributed under the terms of the Creative Commons Attribution License (http://creativecommons.org/licenses/by/2.0), which permits unrestricted use, distribution, and reproduction in any medium, provided the original work is properly cited.

\begin{abstract}
Background: A variant in the promoter of the human uncoupling protein 2 (UCP2) gene, the G-866A polymorphism, has been associated with future risk of coronary heart disease events, in those devoid of traditional risk factors and in those suffering from diabetes. We thus examined the impact of the G-866A polymorphism on 5-year survival in a cohort of 901 post-myocardial infarction patients, and the impact of type- 2 diabetes on this relationship. The association of UCP2 with baseline biochemical and hormonal measurements, including levels of the inflammatory marker myeloperoxidase, was also examined.
\end{abstract}

Methods: UCP2 G-866A genotypes were determined using a polymerase chain reaction-restriction fragment length polymorphism (PCR-RFLP) protocol. Myeloperoxidase levels were measured in plasma samples taken from 419 cohort patients 24-96 hours after admission.

Results: Genotypes were obtained for 90 I patients with genotype frequencies AA I5.5\%, GA 45.5\%, and GG 39.0\%. Genotype was not associated with survival in the overall cohort (mortality: AA I5.6\%, GA I6.8\%, GG I9.4\%, P = 0.54I). However, amongst diabetics, AA and GA genotype groups had significantly worse survival than GG diabetic patients $(p<0.05)$ with an attributable risk of $23.3 \%$ and $18.7 \%$ for those of $\mathrm{AA}$ and GA genotype respectively. Multivariate analysis using a Cox proportional hazards model confirmed that the interaction of diabetes with genotype was significantly predictive of survival $(p=0.03 \mathrm{I})$. In the cohort's diabetic subgroup AA/GA patients had higher myeloperoxidase levels than their GG counterparts (GA/AA, $n=5 \mathrm{I}, 63.9 \pm 5.23$; $\mathrm{GG}, \mathrm{n}=34,49 . \mathrm{I} \pm 3.72 \mathrm{ng} / \mathrm{ml}, \mathrm{p}=0.04 \mathrm{I})$. Further analysis showed that this phenomenon was confined to male patients $(\mathrm{GA} /$ $\mathrm{AA}, \mathrm{n}=36,64.3 \pm 6.23 ; \mathrm{GG}, \mathrm{n}=29,44.9 \pm 3.72 \mathrm{ng} / \mathrm{ml}, \mathrm{p}=0.015)$.

Conclusion: Diabetic patients in this post-myocardial infarction cohort with UCP2 -866 AA/GA genotype have poorer survival and higher myeloperoxidase levels than their GG counterparts. 


\section{Background}

Uncoupling protein 2 (UCP2) is expressed ubiquitously and is believed to dissipate the proton motive force across the inner mitochondrial membrane $[1,2]$. While UCP1 may play a role in thermogenesis [3], UCP2 may regulate inflammation and apoptosis, and inhibition of the mitochondrial production of reactive oxygen species (ROS) [4]. These functions have important implications for brain and heart disease. experimental inhibition of UCP2 expression increases ROS formation [5,6], a risk factor for atherosclerosis [7]. UCP2 has recently been shown to mediate some of the actions of ghrelin [8], a circulating hormone elevated during fasting and with known actions on the heart [9].

Polymorphisms in the UCP2 gene have been associated with obesity [10-12], hypertension [13], and diabetes [14]. A common variant in the promoter of the human UCP2 gene (G-866A, rs659366)[11] has been associated with differential UCP2 expression [12] and elevated levels of markers of oxidative stress amongst diabetics $[15,16]$. The A allele has been associated with enhanced UCP2 expression in adipose tissue in vivo[11]. Indeed, in a prospective study of 2695 men, those with -866AA genotype exhibited a greater prevalence of obesity and hypertension, and a shorter time to first coronary heart disease (CHD) event. This risk was amplified fourfold in diabetic -866AA men [15].

The enzyme myeloperoxidase (MPO, EC 1.11.1.7) is mainly released by activated neutrophils with pro-oxidative and pro-inflammatory properties. Given the role of inflammation in atherogenesis, MPO is a biomarker of coronary artery disease [17]. Meanwhile, infiltrating macrophages and neutrophils play a role in the destabilization of coronary artery plaques and thus in the pathogenesis of acute coronary syndromes including myocardial infarction (MI)[18].

We thus hypothesized that the UCP2 G-866A polymorphism might be associated with survival in a study sample at high risk of future cardiovascular events, and that this relationship might be stronger amongst diabetics. Given the proinflammatory role of UCP2 [4], we also sought association of UCP2 genotype with plasma MPO levels in this group.

\section{Methods}

\section{Study Population}

Patients were admitted to Christchurch Hospital between November 1994 and June 2001 and recruited to the Christchurch Post-Myocardial Infarction (PMI) study using criteria described previously [19]. Briefly, MI was defined by typical ischemic symptoms, ischemic change (including ST-elevation or depression or dynamic T-wave changes, i.e. includes ST-elevation, non-ST-elevation, Qwave, and non-Q-wave infarcts) in two or more electrocardiogram leads and peak elevation of plasma creatine kinase (CK) to at least twice the upper limit of normal. All patients were troponin- $T$ positive. Inclusion criteria included age $<80$ years, absence of immediate heart failure or cardiogenic shock, and survival for at least $24 \mathrm{~h}$ after the onset of symptoms associated with MI. Patients were followed for 5 years and data on mortality/survival for the full 5 years of follow-up was available for all patients in the cohort. Blood samples and cardiac imaging were obtained 24-96 h after symptom onset. Clinical events were determined from recruitment questionnaires, planned follow-up clinic visits, patient notes, the New Zealand National Health Information Service and hospital Patient Management System databases. Ethnicity was self-declared and was grouped as those of European, Maori, Not Stated and Other (Asian, African and Pacific Islanders) ancestry. The investigation conforms to the principles outlined in the Declaration of Helsinki and was approved by the Canterbury Ethics Committee. All participating patients provided written, informed consent.

\section{Dna Extraction and Genotyping}

Genomic DNA was extracted from whole blood as previously described [20]. DNA (100 ng) was amplified for the UCP2 G-866A PCR-RFLP assay, in which 360 bp amplimers were digested for $16 \mathrm{~h}$ at $37^{\circ} \mathrm{C}$ using $2.5 \mathrm{U}$ of $\mathrm{Mlu \textrm {I }}$ [11]. The digested, gel-electrophoresed fragments were visualized using a Bio-Rad Fluor- $S^{\mathrm{TM}}$ imaging system.

\section{Neurohormone, Analyte and Cardiac Imaging Measurements}

Circulating levels of endothelin-1, ANP and B-type natriuretic peptide (BNP) and N-terminal pro-BNP (NTproBNP) were assayed as previously described [19]. creatinine clearance was calculated using the CockcroftGault formula [21]. Levels of creatine kinase (CK) were measured using ELISA kits (Roche Diagnostics, Auckland, $\mathrm{NZ}$ ). Left ventricular function was assessed by radionuclide ventriculography - within 24-96 hours of onset of MI (within 24 hours of blood sampling) [22]. Myeloperoxidase (EC 1.11.1.7) was measured by sandwich ELISA on plasma diluted 1:10, with a monoclonal antibody (Abcam, Cambridge, United Kingdom) and a rabbit polyclonal antibody produced in-house [23], with a detection range of 0.3 to $25 \mathrm{ng} / \mathrm{ml}$ and coefficient of variance of $13.8 \%$.

\section{Statistical Analysis}

Univariate analysis, relating UCP2 G-866A genotype status to other variables, was performed using $\chi^{2}$ and ANOVA tests. Skewed data (notably plasma hormones) were log-transformed. Survival was assessed using KaplanMeier survival curves and log-rank tests. Due to the small 
number of UCP2 -866 AA patients for which MPO levels were available data for AA and GA patients was grouped for this analysis. A Cox proportional hazard model was used to investigate independent risk factors for all-cause mortality. The model included established predictors of prognosis (age, gender, NTproBNP and CK levels, admission left ventricular ejection fraction (LVEF), $\beta$-blocker treatment, and creatinine clearance) $[20,22,24,25]$. Statistical significance was deemed to be achieved at the $\mathrm{p}<$ 0.05 level. The statistical power of the study was estimated from the cohort's likely genotype split of $15 \%$ (AA) and $\sim 42.5 \%$ (GG or GA respectively) [11,15] with a total $\mathrm{n}$ of $\sim 900$ and an event (mortality) rate of approximately 3\% per annum and complete follow-up to 5 years. Thus there was $80 \%$ power to detect $>10 \%$ difference in mortality between the two homozygote groups, using a two-tailed $\chi^{2}$ test, $\alpha=0.05$. All analyses were performed using SPSS version 16 .

\section{Results}

\section{Baseline Characteristics and UCP2 Genotyping}

Of an available cohort of 982, genotypes were obtained for 901 patients with genotype frequencies AA 15.5\%, GA 45.5\%, and GG 39.0\% which did not deviate from the Hardy-Weinberg equilibrium ( $\mathrm{p}=0.999)$. The minor allele (A) frequency was 0.38 , similar to that reported elsewhere $[11,15]$. Baseline characteristics stratified by UCP2 G-866A genotype group are shown in Table 1, and did not differ from those in whom genotyping was not possible. Only patient gender was significantly associated with genotype, with the proportion of males increasing with the number of $\mathrm{G}$ alleles. Ethnicity was not significantly associated with differences in genotype frequency (minor allele frequencies: European 0.375, Maori 0.438, Not Stated 0.442, Other 0.371, p = 0.481).

\section{Survival and UCP2 Genotype}

A total of 159 deaths were recorded in the study cohort during the 5-year follow-up. UCP2 G-866A genotype was

Table I: Baseline characteristics, drug treatment and neurohormonal data stratified by UCP2 genotype group.

\begin{tabular}{|c|c|c|c|c|c|c|c|}
\hline & \multicolumn{7}{|c|}{ UCP2 Genotype } \\
\hline & $\mathbf{n}$ & AA & $\mathbf{n}$ & GA & $\mathbf{n}$ & GG & $\mathbf{p}$ \\
\hline Gender (M/F) & 140 & $102 / 38(72.9 \% M)$ & 410 & $309 / 101(75.4 \% M)$ & 351 & $292 / 59(83.2 \% M)$ & 0.009 \\
\hline Age (years)* & 140 & $61.5 \pm 0.94$ & 410 & $62.0 \pm 0.49$ & 350 & $62.7 \pm 057$ & 0.404 \\
\hline $\mathrm{BMI} *\left(\mathrm{kgm}^{-2}\right)$ & 92 & $27.2 \pm 0.51$ & 285 & $26.9 \pm 0.25$ & 239 & $26.4 \pm 0.25$ & 0.174 \\
\hline LVEF & 113 & $47.2 \pm 1.00$ & 348 & $48.0 \pm 0.64$ & 288 & $47.9 \pm 0.72$ & 0.822 \\
\hline Predischarge Mean arterial pressure $(\mathrm{mmHg})$ & 133 & $82.9 \pm 0.87$ & 397 & $83.2 \pm 0.55$ & 341 & $84.6 \pm 0.61$ & 0.145 \\
\hline Predischarge Systolic Blood pressure $(\mathrm{mmHg})$ & 133 & $117 \pm 1.28$ & 397 & $116 \pm 0.81$ & 341 & $118 \pm 0.90$ & 0.163 \\
\hline Predischarge Diastolic Blood pressure $(\mathrm{mmHg})(\mathrm{mmHg})$ & 133 & $65.9 \pm 0.82$ & 397 & $66.8 \pm 0.54$ & 341 & $67.8 \pm 0.57$ & 0.176 \\
\hline \multicolumn{8}{|l|}{ History } \\
\hline Previous myocardial infarction* & 127 & $24(18.9 \%)$ & 389 & $72(18.5 \%)$ & 334 & $58(17.4 \%)$ & 0.896 \\
\hline hypertension * & 129 & $47(36.4 \%)$ & 400 & $157(39.3 \%)$ & 342 & $|3|(38.3 \%)$ & 0.847 \\
\hline Type 2 Diabetes* & 139 & $22(15.8 \%)$ & 409 & $48(\mid 1.7 \%)$ & 349 & $38(10.9 \%)$ & 0.308 \\
\hline $\begin{array}{l}\text { Predischarge Atrial Fibrillation* } \\
\text { Fibrillation* }\end{array}$ & 112 & $12(10.7 \%)$ & 346 & $35(10.1 \%)$ & 297 & $47(15.8 \%)$ & 0.076 \\
\hline Predischarge Ventricular Fibrillation* Fibrillation* & 113 & $\mathrm{II}(9.7 \%)$ & 355 & 40 । $1.3 \%)$ & 300 & $21(7.0 \%)$ & 0.173 \\
\hline \multicolumn{8}{|l|}{ Laboratory Data } \\
\hline Total Cholesterol* $(\mathrm{mmol} / \mathrm{l})$ & 130 & $5.94 \pm 0.10$ & 376 & $5.95 \pm 0.065$ & 330 & $5.81 \pm 0.068$ & 0.325 \\
\hline HDL Cholesterol* (mmol/l) & 129 & $1.16 \pm 0.026$ & 371 & $1.16 \pm 0.017$ & 325 & $1.15 \pm 0.018$ & 0.913 \\
\hline LDL Cholesterol* (mmol/ll) & 97 & $3.96 \pm 0.10$ & 299 & $3.98 \pm 0.058$ & 268 & $3.83 \pm 0.069$ & 0.225 \\
\hline Triglycerides* $(\mathrm{mmol} / \mathrm{l})$ & 130 & $2.02 \pm 0.11$ & 376 & $2.08 \pm 0.096$ & 330 & $2.01 \pm 0.069$ & 0.791 \\
\hline Plasma Creatinine $\nmid(\mu \mathrm{mol} / \mathrm{l})$ & 136 & $83(79-87)$ & 405 & $85(82-87)$ & 347 & $85(83-87)$ & 0.600 \\
\hline Creatinine Clearance* (ml/s) & 99 & $1.28 \pm 0.047$ & 308 & $1.28 \pm 0.023$ & 267 & $1.32 \pm 0.028$ & 0.546 \\
\hline Peak Creatine kinasef (units/l) & 105 & $1440(1250-1660)$ & 327 & $1610(1480-1740)$ & 269 & $1640(1510-1680)$ & 0.304 \\
\hline Plasma Glucose $(\mathrm{mmol} / \mathrm{l})$ & 137 & $8.55 \pm 0.27$ & 404 & $8.64 \pm 0.15$ & 344 & $8.55 \pm 0.16$ & 0.912 \\
\hline Glycated Hemoglobin \% & 105 & $6.07 \pm 0.11$ & 324 & $6.06 \pm 0.06$ & 274 & $6.03 \pm 0.06$ & 0.905 \\
\hline \multicolumn{8}{|l|}{ Discharge Medications } \\
\hline ACE inhibitor * & 122 & $36(29.5 \%)$ & 374 & 121 (32.4\%) & 318 & $109(34.3 \%)$ & 0.624 \\
\hline$\beta$-blocker * & 122 & $78(63.9 \%)$ & 374 & $232(62.0 \%)$ & 318 & $176(55.3 \%)$ & 0.119 \\
\hline \multicolumn{8}{|l|}{ Neurohormonal Data } \\
\hline ANP $(\mathrm{pmol} / \mathrm{l}) \ddagger$ & 138 & 26.8(24.4-29.4) & 403 & $28.5(27.0-30.0)$ & 346 & $28.8(27.1-30.6)$ & 0.406 \\
\hline $\mathrm{BNP}(\mathrm{pmol} / \mathrm{l}) \ddagger$ & 138 & $18.2(16.4-20.2)$ & 404 & $19.8(\mid 8.7-21.0)$ & 346 & $19.9(|8.8-2| .1)$ & 0.290 \\
\hline NTproBNP (pmol/l) $\ddagger$ & 137 & $98.6(87.0-112)$ & 399 & $112(104-121)$ & 344 & $111(103-121)$ & 0.200 \\
\hline Endothelin-I $(\mathrm{pmol} / \mathrm{l}) \ddagger$ & 137 & $1.64(1.52-1.77)$ & 398 & $1.80(1.73-1.88)$ & 340 & $1.76(1.167-1.81)$ & 0.110 \\
\hline
\end{tabular}

*Means (SEM) or occurrence (percentage); † Median (range); $\ddagger$ Geometric mean ( $95 \%$ confidence interval). 
A

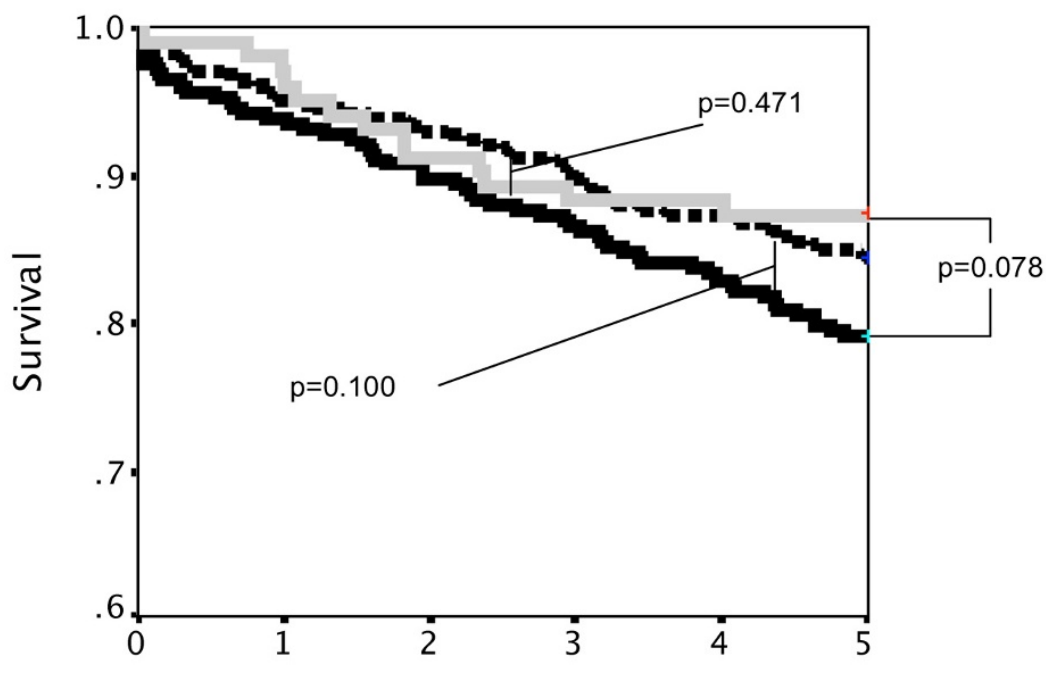

\begin{tabular}{|c|c|c|c|c|c|c|}
\hline \multirow[b]{2}{*}{ UCP2 -866 AA 103} & \multicolumn{4}{|c|}{ Years } & \multicolumn{2}{|r|}{ Events } \\
\hline & 100 & 94 & 91 & 90 & 89 & $13(12.6 \%)$ \\
\hline UCP2 -866 GA - 330 & 314 & 307 & 296 & 288 & 277 & $52(15.8 \%)$ \\
\hline UCP2 -866 GG 283 & 266 & 254 & 245 & 235 & 224 & $59(20.8 \%)$ \\
\hline
\end{tabular}

B

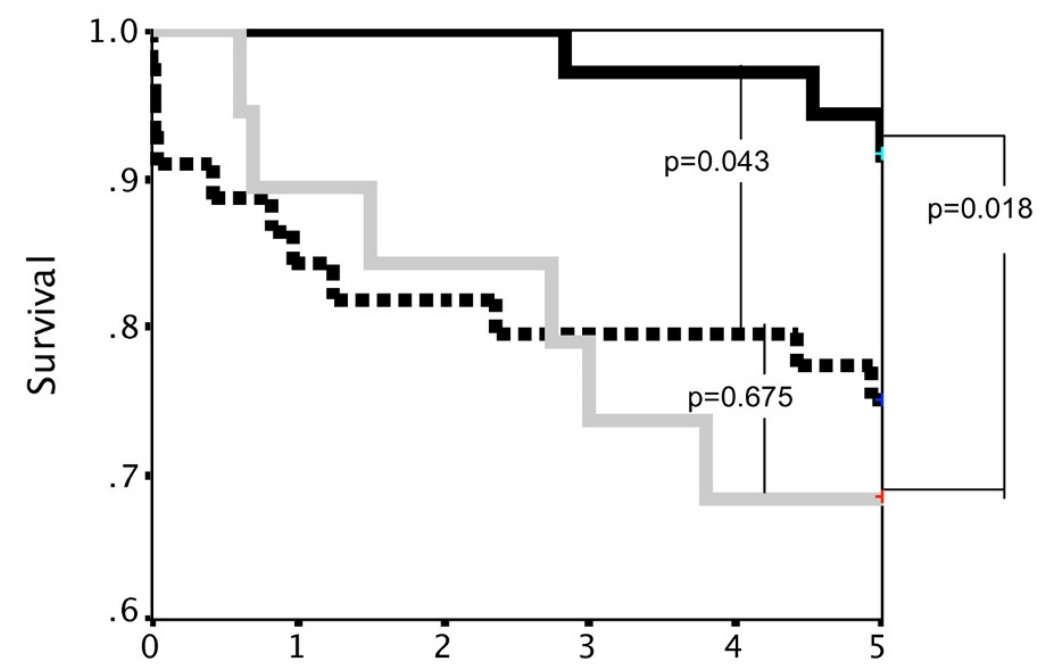

\begin{tabular}{llllllc} 
& \multicolumn{9}{c}{ Years } & \multicolumn{2}{c}{ Events } \\
UCP2 -866 AA $=19$ & 17 & 16 & 14 & 13 & 12 & $6(31.5 \%)$ \\
UCP2 -866 GA- - 44 & 37 & 36 & 35 & 35 & 32 & $11(15.8 \%)$ \\
UCP2 -866 GG $=36$ & 36 & 36 & 35 & 35 & 33 & $3(8.3 \%)$
\end{tabular}

Figure I

A Kaplan-Meier survival curve indicating differences in survival after MI for UCP2 G-866A genotype groups in A) non-diabetic patients and B) diabetic patients. 
Table 2: Cox's proportional hazards regression model for mortality in the PMI cohort.

\begin{tabular}{|c|c|c|c|c|c|c|c|}
\hline & Coefficient & SE & Wald & $\mathrm{df}$ & Significance & Hazard Ratio & $95 \% \mathrm{Cl}$ for Hazard Ratio \\
\hline Age & 0.018 & 0.016 & 1.40 & 1 & 0.237 & 1.02 & $0.99-1.05$ \\
\hline Gender & 0.587 & 0.270 & 4.71 & 1 & 0.030 & 1.80 & $1.06-3.06$ \\
\hline ACE inhibitor (No/Yes) & 0.235 & 0.229 & 1.06 & 1 & 0.303 & 1.27 & $0.81-1.98$ \\
\hline LVEF (I-4 days post-MI) & -0.013 & 0.011 & 1.48 & I & 0.224 & 0.99 & $0.97-1.01$ \\
\hline $\log _{10}$ NTproBNP* & 1.55 & 0.409 & 14.3 & 1 & $<0.001$ & 4.70 & $2.11-10.5$ \\
\hline Log $_{10}$ peak creatine kinase* & 1.11 & 0.338 & 10.8 & 1 & 0.001 & 3.04 & $1.56-5.88$ \\
\hline Creatinine clearance & -0.900 & 0.384 & 5.49 & 1 & 0.019 & 0.406 & $0.19-0.86$ \\
\hline Ethnicity (European v non-European) & 1.05 & 0.597 & 3.11 & 1 & 0.078 & 2.86 & $0.89-9.21$ \\
\hline Type 2 Diabetes & 0.847 & 0.602 & 1.98 & 1 & 0.159 & 2.33 & $0.72-7.59$ \\
\hline UCP2 G-866A genotype & & & 4.91 & 2 & 0.086 & & \\
\hline$G G \vee A A$ & 1.64 & 0.747 & 4.79 & 1 & 0.029 & 5.13 & $1.19-22.2$ \\
\hline $\mathrm{GG} \vee \mathrm{GA}$ & 1.16 & 0.684 & 2.89 & 1 & 0.089 & 3.19 & $0.841-12.2$ \\
\hline Diabetes $\times$ UCP2 genotype & & & 6.92 & 2 & 0.031 & & \\
\hline Diabetes $\times$ UCP2 genotype $(G G \vee A A)$ & 1.52 & 0.725 & 4.40 & 1 & 0.036 & 4.59 & $1.10-18.9$ \\
\hline Diabetes $\times$ UCP2 genotype (GG v GA) & 2.09 & 0.826 & 6.40 & I & 0.011 & 8.06 & $1.60-40.0$ \\
\hline
\end{tabular}

\footnotetext{
* Hazard Ratio represents the change in risk for every 10 -fold increase in measurement level.
}

not associated with survival in the overall cohort (mortality: AA $15.6 \%$, GA $16.8 \%$, GG $19.4 \%$, p = 0.541). However when the cohort was stratified according to prior diagnosis of type-2 diabetes, genotype was significantly associated with survival amongst diabetic patients (Figure $1)$. Diabetic patients of AA or GA genotype had significantly worse survival than GG diabetic patients ( $p<0.05)$, with an attributable risk of $23.3 \%$ and $18.7 \%$ respectively. Multivariate analysis using a Cox proportional hazards model confirmed that UCP2 G-866A genotype alone was not a significant predictor of survival in the cohort, although there were trends in that direction (Table 2). However the interaction of diabetes with genotype was significantly predictive of survival in a model including age, gender, NTproBNP and CK levels, left ventricular ejection fraction, creatinine clearance, ethnicity, $\beta$-blocker treatment, diabetes and genotype (Table 2). Inclusion of additional covariates to the multivariate model did not add significantly to it (e.g. baseline total cholesterol Hazard Ratio $=1.17[0.96-1.43] \mathrm{p}=0.131$; mean arterial pressure HR $=1.01[0.99-1.04] \mathrm{p}=0.240$ ) and exceeded the recommended number of predictors given the number of events in the analysis.

\section{UCP2 Genotype and Plasma Myeloperoxidase Levels}

Plasma MPO levels were available from samples taken from 419 patients in the cohort 24-96 hours after admission. These patients were selected only by the availability of adequate stored plasma for the measurement of MPO and we believe this selection was essentially random. Whilst there was no overall association of UCP2 genotype, diabetic status or gender with MPO levels, there was a significant interaction of gender*diabetic status*UCP2 genotype in a univariate general linear model $(\mathrm{p}=0.037)$. In the diabetic subgroup of the cohort, patients with at least one A allele had significantly higher MPO levels than their
GG counterparts (GA/AA, $\mathrm{n}=51,63.9 \pm 5.23 \mathrm{ng} / \mathrm{ml}$; GG, $\mathrm{n}=34,49.1 \pm 3.72 \mathrm{ng} / \mathrm{ml}, \mathrm{p}=0.041$; Figure 2$)$. This phenomenon was only apparent in male patients (GA/AA, $n$ $=36,64.3 \pm 6.23 \mathrm{ng} / \mathrm{ml} ; \mathrm{GG}, \mathrm{n}=29,44.9 \pm 3.72 \mathrm{ng} / \mathrm{ml}, \mathrm{p}$ $=0.015$; Figure 2). There was no significant association between genotype and MPO levels in female diabetic patients (GA/AA, $\mathrm{n}=15,62.9 \pm 9.99 \mathrm{ng} / \mathrm{ml} ; \mathrm{GG}, \mathrm{n}=5$, $73.5 \pm 6.17 \mathrm{ng} / \mathrm{ml}, \mathrm{p}=0.561)$ or amongst non-diabetic patients (data not shown). MPO levels did not differ significantly between diabetic and non-diabetic patients (diabetics, $\mathrm{n}=85,58.0 \pm 3.27 \mathrm{ng} / \mathrm{ml}$; non-diabetics, $\mathrm{n}=$ $334,63.7 \pm 2.21 \mathrm{ng} / \mathrm{ml}, \mathrm{p}=0.223)$.

\section{Discussion}

The major finding of this study is that the interaction between type-2 diabetes and UCP2 G-866A genotype was significantly associated with survival in a cohort of postMI patients. The UCP2-866A allele carriers had significantly worse survival during 5 years of follow-up post-MI than GG patients if they were diabetic. These data extend previous observations amongst otherwise healthy men in whom the UCP2 G-866A genotype was associated with future risk of CHD events, both in those individuals devoid of traditional risk factors for cardiovascular disease and amongst the small proportion of diabetic patients [15]. In contrast a study of 3122 type- 2 diabetic patients reported association of the UCP2 -866 A allele with decreased risk of incident coronary artery disease, including sudden cardiac death [26]. The disease-free survival profile in this report closely resembles the survival curve for non-diabetic patients in our study (Figure 1A). This inconsistency may have several explanations: study endpoints differed (survival versus disease-free survival) and differing age and ethnic profiles. 


\section{A) Males and Females}

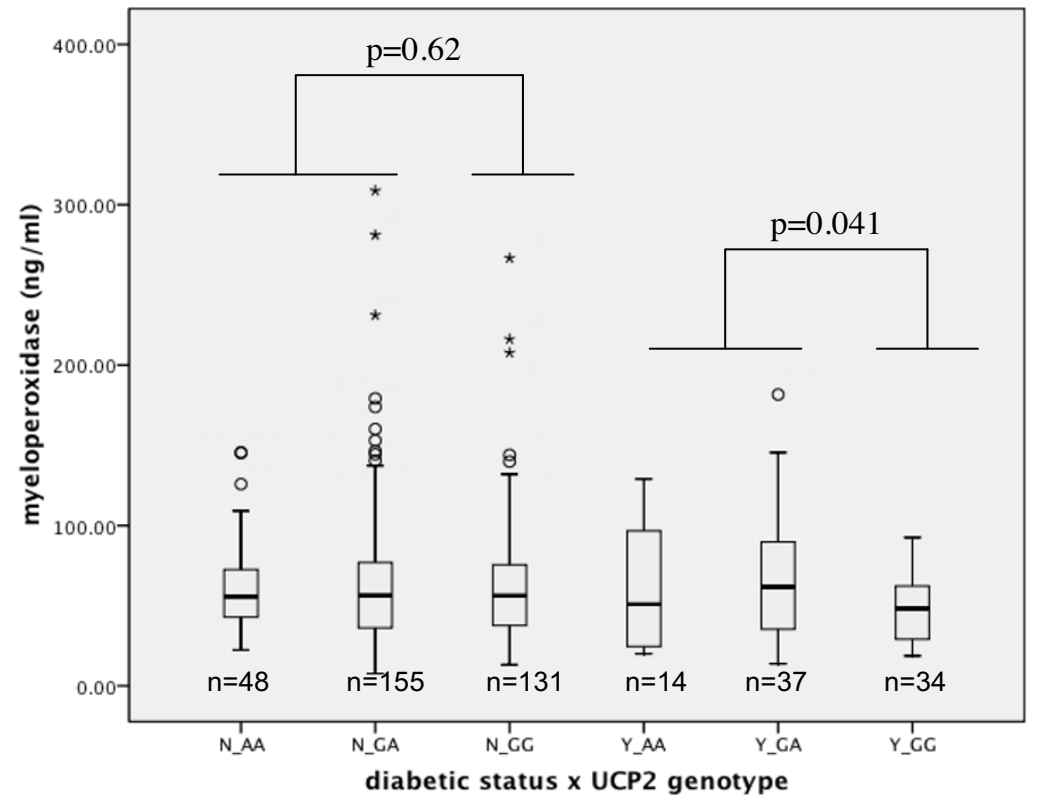

B) Males only

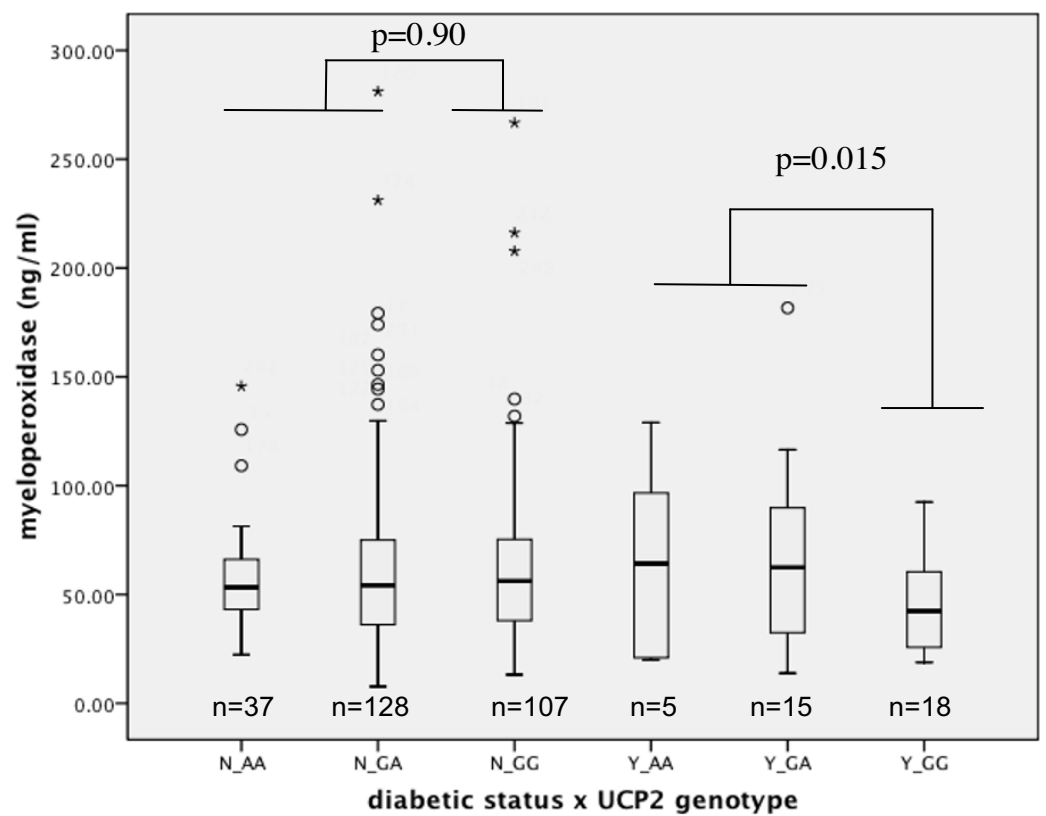

\section{Figure 2}

Plasma myeloperoxidase levels 24-96 hours after index patient admission stratified by UCP2 G-866A genotype and diabetic status a) Male and Female patients, b) Male patients. $N=$ non-diabetic, $Y=$ diabetic. Stars and circles indicate outlying data. 
Diabetes is associated with increased oxidative stress [27] and diabetic patients with the UCP2-866AA genotype and CHD have been shown to have lower total antioxidant status and higher levels of plasma F2-isoprostanes [15]. Elevated levels of plasma MPO, has previously been shown to be a predictor of mortality in the cohort studied in this report [28]. The difference observed in MPO levels between GA/AA and GG diabetic patients was of similar magnitude to that observed between heart healthy control subjects and PMI patients in the previous report [28]. We did not include MPO as a predictor in the multivariate model of survival as missing data would have severely restricted the number of patients in the analysis. While this data was not well powered to detect differences in MPO levels based on UCP2 genotypes groups, we did detect an association of MPO levels and genotype amongst diabetic patients in this study. This was particularly evident in male diabetic patients in the cohort, a finding consistent with previous reports of gender specific differences in oxidative stress $[29,30]$. This finding of an association between UCP2 G-866A genotype and plasma MPO levels can be regarded as hypothesis generating and requires validation in other studies.

Although the current study has considerable statistical power, due to the size of the cohort, the length of followup, the number of clinical endpoints recorded and the minor allele frequency of the G-866A polymorphism, statistically significant differences may have occurred by chance and weak associations may have been missed. Missing data for some parameters has limited the power of this study to investigate their association with genotype. The study cohort was dominated by ethnic Europeans and the results should not be extrapolated to other populations.

\section{Conclusion}

Our data provide support for the idea that modulation of UCP2 expression might be an important novel target for reducing cardiovascular morbidity and mortality, particularly amongst diabetic patients [31]. A growing body of evidence supports the UCP2 G-866A polymorphism as a marker of cardiovascular risk $[15,16,32]$. This study extends this evidence to include UCP2 genotype as a potential marker of prognosis in type- 2 diabetes patients following acute MI.

\section{Abbreviations}

UCP2: uncoupling protein 2 gene; ROS: reactive oxygen species; MPO: myeloperoxidase; PMI: Post-Myocardial Infarction; BNP: B-type natriuretic peptide; NTproBNP: Nterminal pro-BNP; CK: creatine kinase; LVEF: left ventricular ejection fraction; CHD: coronary heart disease.

\section{Competing interests}

The authors declare that they have no competing interests.

\section{Authors' contributions}

BRP, SSD and HEM conceived the study and the experimental design and BRP, CLD and TJM performed the data acquisition and interpreted the results. TGY was responsible for hormone assay data acquisition and interpretation. BRP, CMF and HEM drafted the manuscript. APP, VAC, AMR, CCW, LS, SSD and HEM interpreted the results and critically reviewed the manuscript adding important intellectual content. All authors read and approved the final version of the manuscript.

\section{Acknowledgements}

We thank the participants in the PMI study, Endolab and Christchurch Cardiology Outpatient staff. The Health Research Council and the National Heart Foundation (NHF) of New Zealand supported this work. CLD participated in the Butler-IFSA study abroad program at the University of Canterbury, Christchurch. APP held a Foundation of Research, Science and Technology Postdoctoral Fellowship and AMR held the NHF Chair of Cardiovascular Studies.

\section{References}

I. Fleury C, Neverova M, Collins S, Raimbault S, Champigny O, LeviMeyrueis C, Bouillaud F, Seldin MF, Surwit RS, Ricquier D, et al.: Uncoupling protein-2: a novel gene linked to obesity and hyperinsulinemia. Nature genetics 1997, I 5(3):269-272.

2. Garlid KD, Jaburek M, Jezek P: Mechanism of uncoupling protein action. Biochem Soc Trans 200I, 29(Pt 6):803-806.

3. Brand MD, Esteves TC: Physiological functions of the mitochondrial uncoupling proteins UCP2 and UCP3. Cell Metab 2005, 2(2):85-93

4. Mattiasson G, Sullivan PG: The emerging functions of UCP2 in health, disease, and therapeutics. Antioxid Redox Signal 2006 , 8(I-2): I-38.

5. Duval C, Negre-Salvayre A, Dogilo A, Salvayre R, Penicaud L, Casteilla $L$ : Increased reactive oxygen species production with antisense oligonucleotides directed against uncoupling protein 2 in murine endothelial cells. Biochem Cell Biol 2002 80(6):757-764.

6. Arsenijevic D, Onuma $\mathrm{H}$, Pecqueur $\mathrm{C}$, Raimbault $\mathrm{S}$, Manning BS, Miroux B, Couplan E, Alves-Guerra MC, Goubern M, Surwit R, et al.: Disruption of the uncoupling protein- 2 gene in mice reveals a role in immunity and reactive oxygen species production. Nature genetics 2000, 26(4):435-439.

7. Blanc J, Alves-Guerra MC, Esposito B, Rousset S, Gourdy P, Ricquier $D$, Tedgui A, Miroux B, Mallat Z: Protective role of uncoupling protein 2 in atherosclerosis. Circulation 2003, I07(3):388-390.

8. Andrews ZB, Liu Z-W, Wallingford N, Erion DM, Borok E, Friedman JM, Tschop MH, Shanabrough M, Cline G, Shulman GI, et al.: UCP2 mediates ghrelin/'s action on NPY/AgRP neurons by lowering free radicals. Nature 2008, 454(7206):846-85I.

9. Pemberton Cl, Tokola H, Bagi Z, Koller A, Pontinen J, Ola A Vuolteenaho O, Szokodi I, Ruskoaho H: Ghrelin induces vasoconstriction in the rat coronary vasculature without altering cardiac peptide secretion. American journal of physiology 2004, 287(4):HI522-I529.

10. Ochoa MC, Santos JL, Azcona C, Moreno-Aliaga MJ, MartinezGonzalez MA, Martinez JA, Marti A: Association between obesity and insulin resistance with UCP2-UCP3 gene variants in Spanish children and adolescents. Mol Genet Metab 2007, 92(4):35I-8.

II. Esterbauer H, Schneitler C, Oberkofler H, Ebenbichler C, Paulweber B, Sandhofer F, Ladurner G, Hell E, Strosberg AD, Patsch JR, et al:: A common polymorphism in the promoter of UCP2 is associated with decreased risk of obesity in middle-aged humans. Nature genetics 200 I, 28(2): I78-I83. 
12. Krempler F, Esterbauer H, Weitgasser R, Ebenbichler C, Patsch JR, Miller K, Xie M, Linnemayr V, Oberkofler H, Patsch W: A functional polymorphism in the promoter of UCP2 enhances obesity risk but reduces type 2 diabetes risk in obese middle-aged humans. Diabetes 2002, 5 I ( I I):333 I-3335.

13. Ji Q, Ikegami H, Fujisawa T, Kawabata Y, Ono M, Nishino M, Ohishi $M$, Katsuya $T$, Rakugi $H$, Ogihara $T$ : A common polymorphism of uncoupling protein 2 gene is associated with hypertension. J Hypertens 2004, 22(I):97-102.

14. Sesti G, Cardellini M, Marini MA, Frontoni S, D'Adamo M, Del Guerra S, Lauro D, De Nicolais P, Sbraccia P, Del Prato S, et al.: A common polymorphism in the promoter of UCP2 contributes to the variation in insulin secretion in glucose-tolerant subjects. Diabetes 2003, 52(5): I 280-I283.

15. Dhamrait SS, Stephens JW, Cooper JA, Acharya J, Mani AR, Moore K, Miller GJ, Humphries SE, Hurel SJ, Montgomery HE: Cardiovascular risk in healthy men and markers of oxidative stress in diabetic men are associated with common variation in the gene for uncoupling protein 2. Eur Heart J 2004, 25(6):468-475.

16. Stephens JW, Dhamrait SS, Mani AR, Acharya J, Moore K, Hurel S], Humphries SE: Interaction between the uncoupling protein 2 866G >A gene variant and cigarette smoking to increase oxidative stress in subjects with diabetes. Nutr Metab Cardiovasc Dis 2007, I8(I):7-14.

17. Loria V, Dato I, Graziani F, Biasucci LM: Myeloperoxidase: a new biomarker of inflammation in ischemic heart disease and acute coronary syndromes. Mediators of inflammation 2008, 2008: I35625.

18. Naruko T, Ueda M, Haze K, Wal AC van der, Loos CM van der, Itoh A, Komatsu R, lkura Y, Ogami M, Shimada Y, et al.: Neutrophil infiltration of culprit lesions in acute coronary syndromes. Circulation 2002, I06(23):2894-2900.

19. Richards A, Nicholls M, Yandle T, Ikram H, Espiner E, Turner J, Buttimore R, Lainchbury J, Elliott J, Frampton C, et al: Neuroendocrine prediction of left ventricular function and heart failure after acute myocardial infarction. Heart 1999, 81(2): | |4-|20.

20. Palmer B, Pilbrow A, Frampton C, Yandle T, Nicholls M, Richards A, Cameron V: ACE gene polymorphism interacts with LVEF and BNP levels to predict mortality following myocardial infarction. Journal of the American College of Cardiology 2003, 4 I(5):729-736.

21. Cockcroft DW, Gault MH: Prediction of creatinine clearance from serum creatinine. Nephron 1976, I6(I):31-4I.

22. Richards AM, Nicholls MG, Espiner EA, Lainchbury JG, Troughton RW, Elliott J, Frampton C, Turner J, Crozier IG, Yandle TG: B-type natriuretic peptides and ejection fraction for prognosis after myocardial infarction. Circulation 2003, 107(22):2786-2792.

23. Cameron VA, Mocatta T], Pilbrow AP, Frampton CM, Troughton RW, Richards AM, Winterbourn CC: Angiotensin type-I receptor AI I66C gene polymorphism correlates with oxidative stress levels in human heart failure. Hypertension 2006, 47(6): II55-| I6I.

24. Baird TE, Palmer BR, Frampton CM, Yandle TG, Skelton L, Richards $A M$, Cameron VA: Association of the aldosterone synthase gene C-344T polymorphism with risk factors and survival in a post-myocardial infarction cohort. J Hum Hypertens 2007, 2 I (3):256-258.

25. Collins RP, Palmer BR, Pilbrow AP, Frampton CM, Troughton RW, Yandle TG, Skelton L, Richards AM, Cameron VA: Evaluation of AMPDI C34T genotype as a predictor of mortality in heart failure and post-myocardial infarction patients. Am Heart J 2006, I 52(2):312-320.

26. Cheurfa N, Dubois-Laforgue D, Ferrarezi DA, Reis AF, Brenner GM, Bouche C, Le Feuvre C, Fumeron F, Timsit J, Marre M, et al.: The common -866G>A variant in the promoter of UCP2 is associated with decreased risk of coronary artery disease in type 2 diabetic men. Diabetes 2008, 57(4): 1063-1068.

27. Brownlee M: Biochemistry and molecular cell biology of diabetic complications. Nature 200 I, 4I 4(6865):8I3-820.

28. Mocatta TJ, Pilbrow AP, Cameron VA, Senthilmohan R, Frampton CM, Richards AM, Winterbourn CC: Plasma concentrations of myeloperoxidase predict mortality after myocardial infarction. J Am Coll Cardiol 2007, 49(20):1993-2000.

29. Sureda A, Ferrer MD, Tauler P, Tur JA, Pons A: Lymphocyte antioxidant response and $\mathrm{H}_{2} \mathrm{O}_{2}$ production after a swimming session: gender differences. Free radical research 2008 , 42(4):312-319.

30. Vassalle C, Maffei S, Boni C, Zucchelli GC: Gender-related differences in oxidative stress levels among elderly patients with coronary artery disease. Fertility and sterility 2008, 89(3):608-6I3.

31. De Souza CT, Araujo EP, Stoppiglia LF, Pauli JR, Ropelle E, Rocco SA Marin RM, Franchini KG, Carvalheira JB, Saad MJ, et al.: Inhibition of UCP 2 expression reverses diet-induced diabetes mellitus by effects on both insulin secretion and action. Faseb J 2007, 2 I(4): I I53-I I 63.

32. Humphries SE, Cooper JA, Talmud PJ, Miller GJ: Candidate gene genotypes, along with conventional risk factor assessment, improve estimation of coronary heart disease risk in healthy UK men. Clinical chemistry 2007, 53(I):8-16.
Publish with Bio Med Central and every scientist can read your work free of charge

"BioMed Central will be the most significant development for disseminating the results of biomedical research in our lifetime. "

Sir Paul Nurse, Cancer Research UK

Your research papers will be:

- available free of charge to the entire biomedical community

- peer reviewed and published immediately upon acceptance

- cited in PubMed and archived on PubMed Central

- yours - you keep the copyright 